\title{
Technology Matters But Good Teachers Matter More
}

\author{
Geoff Romeo \\ Faculty of Education, Monash University, geoff.romeo@education.monash.edu.au
}

\begin{abstract}
This paper uses the strategic management technique of scenario planning to focus attention on plausible futures for the use of ICT in education and to stimulate strategic thinking about technology, teaching and learning. It begins by looking at some predictions about the use of technology in education and presents two scenarios as vignettes. Both scenarios are about Year 9 students and teachers. The first - If I see another piece of multimedia I think I will puke - describes a teaching learning environment where the technology is in control. The second - e-ngage, e-mpower, e-nable - describes a teaching and learning environment that is technology rich and the learner is in control.
\end{abstract}

\section{EDUCATION AND TECHNOLOGY}

Predictions about the future of education abound, especially visions concerning education and technology. Some of the predictions tend to focus on the technology. Pearson and Cochrane (1994), for example, believed that there would be widespread use of virtual reality for recreation and training, portable translation devices, virtual universities, subliminal learning, powerful expert systems, and broadband networked libraries. For Mooneyham (1993) the merging of entertainment and education enabled by technology, would be a matter of survival as people would not have time to pursue the two as mutually exclusive entities. Spender and Stewart (2002) believe that the future belongs to the e-teacher and the e-learner. There will be a shift to online teaching and learning and the notion of anywhere and at anytime learning will become a reality. Student-centered, project-based learning with peer and tutor support will be the norm and, increasingly, learning and earning will be inextricably linked. This will not mean the demise of the teacher but the role of the teacher will be redefined. E-teachers will no longer be the talking heads at the front of the class; they will be as

The original version of this chapter was revised: The copyright line was incorrect. This has been corrected. The Erratum to this chapter is available at DOI: 10.1007/978-0-387-35701-0_35 
adept with technology as they are with books and they will use new technologies to empower and engage learners. In the digital classroom, technology is infused with the learning process to create knowledge products, the one size fits all curriculum is banished, and digital repositories and learning objects are the new tools of the teaching profession.

Visions 2020 (U.S. Department of Commerce, 2002) informs us that Tele-robots will help students interact with experiments, that three dimensional virtual space that mimics the real space visually, aurally and tactually will be available (Bajscy, 2002), that large multimedia production and research centres will be used by students, that visual prosthesis systems so the blind can see will be used, that students will borrow digipacks rugged mobile personal computer and communication consoles like they used to borrow library books (Chen \& Arnold, 2002), that a world to the desktop interface - providing access to distant experts and archives, enabling collaborations, mentoring and virtual communities of practice will exist, as well as interfaces for ubiquitous computing - wireless devices that infuse virtual resources as we move through the real world, and Alice in Wonderland interfaces - which use avatars, computer based agents and digital artifact in virtual contexts for games and work in virtual reality (Dede, 2002), intelligent toys, game based learning, virtual mentors, internet in your ear, supersimulations and sensors, intelligent laboratory objects (Hinrichs \& Gates, 2002), remote immersion systems - bringing interactive and stimulating classroom experiences to all student populations will also be accessible (Neumann \& Kyriakakis, 2002).

Pausch (2002) is a little more curmudgeonly in his predictions about the future of schooling. He believes that virtual reality will finally arrive but we won't use it, that technology will allow children to access the world's experts on any given topic - but the experts won't have time to respond, that telepresence won't take over, children will still physically go to school touch and general proximity will still matter - and that children won't learn to reason, make better judgments, become better citizens because of the technology - they will still need good adult role models (Pausch, 2002).

Other predictions about the future of education tend to focus not so much on the technology, but on the intersection between pedagogy and technology, and its effect on psychology, epistemology and teaching praxis. In Australia a constant theme underpinning the introduction of technology into classrooms has been the vision of using computers to help establish constructivist, humanistic, child centered approaches to teaching and learning based on the integration of the curriculum and inquiry learning (Romeo, 2000). Similarly in the US there has been a series of books, articles and reports predicting a teaching and learning future that exploits the technology to engage and empower learners - see for example Education 
and Technology: Future Visions (Office of Technology \& Assessment, 1994).

A common theme underpinning this notion of an intersection between technology and pedagogy, and the future, especially for educationalists, is the notion of constructivism. The early use of technology in educational settings reflected a behaviourist view of teaching and learning. From a technology perspective, the behaviourist approach manifested itself in programmed learning such as that made available by Computer Assisted Learning (CAL), Computer Managed Learning (CML) and Computer Aided Instruction (CAI). Developments in technology, particularly those evident in multimedia, and increased understandings regarding the complexities involved in learning has led to the application of constructivist principles of learning to electronic environments (Hannafin \& Land, 1997, p. 171).

A constructivist view of learning asserts that knowledge is not passively received by learners but actively built as they interpret new information in light of their existing understanding of concepts and phenomena. Philosophically, its roots lie with Plato, Socrates, Kant, and Dewey, all of whom suggested that knowledge does not lie outside the human sphere in a pre-existing form, instead that knowledge is more likely to arise from human experience of the world via the senses. These philosophical ideas were later expanded by Piaget, whose developmental theory of genetic epistemology identified cognitive equilibration as the psychological process by which human experience was converted to knowledge of the world (Hawkins, 1994; Ridgeway \& Passey, 1991; VonGlaserfeld, 1991).

The constructivist view has recently been extended to include the idea of social constructivism (socio-cultural theory), which is generally attributed to Vygotsky's argument that the development or construction of knowledge is actually a socially mediated act. The acquisition of knowledge is viewed as a social process since it is through engagement, enabled by language with a more capable other, that a student will progress to the next level of understanding (Duffy \& Cunningham, 1996, p. 175).

The theme of social constructivism is especially evident in technology teaching and learning futures espoused by writers such as Bosco, Kozma and Grant, Hunter and Goldberg, Cuban, Riel (Office of Technology \& Assessment, 1994), and is strongly evident in many systemic initiatives such as the enGauge project. The enGauge project is concerned with the challenge of preparing students to live, learn and work successfully in today's knowledge based society and identifies six essential conditions - vision, practice, proficiency, equity, access and systems crucial to the effective use of technology for student learning. Under Practice, effective teachers actively engage their students in an ongoing process of enquiry and employ a broad selective range of technologies to add value and alignment across 
curriculum, instruction and assessment. Effective learning environments are technology rich, and conducive to meaningful student engagement (NCREL, 2002). In Australia the push for an education system underpinned by synergies between technology and the ideas of social constructivism is possibly even stronger and is reflected in the rhetoric of many of the curriculum documents produced by various state education departments (see for example Queensland's New Basics Project (Education Queensland, 2002) and Victoria's Early Years Strategy (DE\&Tb, 2002) and Middle Years (DE\&Ta, 2002) projects.

Does all of this speculation about technology and education help us to prepare for a future in which all we can be certain about is change and uncertainty? Or is it merely an amusing distraction? Business tends to be a little more analytical about the future and uses techniques such as scenario planning or scenario analysis to contemplate plausible futures. These techniques may not help us to accurately predict the future but they help us to focus on the issues and perhaps assist us in avoiding undesirable futures.

\section{SCENARIO PLANNING}

Scenario planning was first developed by Pierre Wack (head of corporate planning for Royal Dutch/Shell) in 1973 and further developed by Peter Schwartz (1996). Scenario planning is not an attempt to predict the future; it highlights perceptual limitations and allows trends, issues, and developments to be identified that may otherwise go unnoticed. There are a number of phases associated with scenario planning. The initial phase is the establishment of a focal point. The focal point is an issue on which it is important to develop insight. The next phase is to identify organizational mental models that exist. Next an environmental scan is conducted to determine what forces and trends are impacting on the focal point. From this, key themes are identified and placed on a matrix. The scenarios are then fleshed out and woven into a narrative (College of Marin, 2002).

The focal point selected for this paper is how information and communication technologies (ICT) will impact on teaching and learning and, as discussed, the organisational mental models that exist range from the use of ICT underpinned by socio-cultural theory to stunning technological developments that will make learning faster and easier. The forces and trends impacting include rapidly changing technology, curriculum reform, economic rationalism, accountability, and middle school reform. For the purposes of this paper I have chosen two themes. The first theme, not surprisingly, is the technology itself. In the future we may choose to saturate teaching and learning with technology or not. The second theme is teaching 
and learning theory. In the future we may choose the messy, expensive, rocky road of social constructivism or the highly structured, easily measured - let's do a multiple choice test - road of behaviourism and outcomes based education. The themes are placed on a continuum, intersected, and positioned on a matrix (see Figure 1). From the matrix scenarios are extracted. For the purposes of this paper I have extracted two scenarios and presented them as vignettes. In the first scenario I have drawn heavily on the work of Dede (2002). In the second scenario we meet Sue Shaw - good teacher.

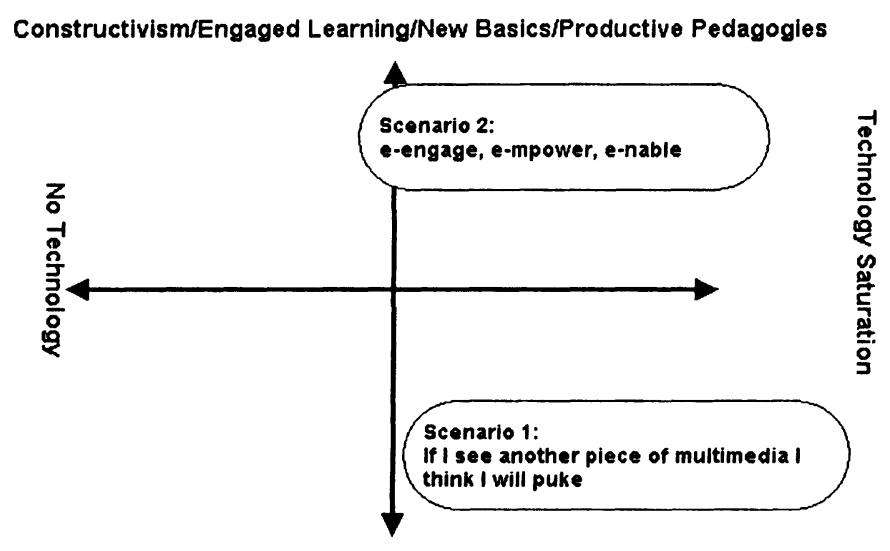

Behaviourism/Rote Learning/Outcomes Based Education

Figure 1. Scenario planning matrix

\subsection{Scenario 1 - If I see another piece of multimedia I think I will puke}

Jessica and Kimberley are in Year 9 at Plato Grammar School (PGS), an expensive private school in Melbourne's south eastern suburbs. Jessica's parents chose this school because of its exceptionally high Victorian Certificate of Education (VCE) scores, its traditional academic curriculum (this school has character building rigour!) and its superior information and communication technologies. The school boasts the best information and communication technologies in the country - ultra-fast workstations, highspeed digital connection to the Internet, video conferencing between campuses, and its crowning glory - AchieveHigh2 - a machine based intelligent tutor system.

AchieveHigh2, manages content for all curriculum areas, assesses students, provides feedback to teachers and parents - including a clever 
system of intelligent web cams that allows parents to monitor students from homes and offices, personalizes instruction - even catering for multiple intelligences and remedial students, utilizes virtual tutors - agents to provide learners with critical friends to assist in the construction of knowledge (that's what the brochure says). AchieveHigh2 cost squillions to develop and Plato Grammar School pays an exorbitant per student licensing fee to LernTek for updates, service packs and access to lightning fast servers located in the US. Version 2.1.4 is due out next year.

The licensing fees are passed on to the clients of course, but Plato Grammar is able to keep costs down and remain competitive because they have their own content development department. The content department has an international reputation for developing quality learning objects. Content and learning objects are now tradable commodities and content developed for AchieveHigh2 by Plato Grammar is sold back to LernTek who then onsell it to other schools. Plato Grammar also saves money by manipulating student-teacher ratios. AchieveHigh2 is not only capable of monitoring student learning but it can also monitor and manage student behaviour. Virtual behaviour monitoring agents patrol the virtual and physical space making a simple trip to the bathroom a worrying ordeal for those who do not take the direct route. Now only one human teacher is needed for 150 pupils and five classrooms.

This morning, Jessica and Kimberley have arrived at school to be told that the output for Year 9 is to be increased by $5 \%$ because they have not been working hard enough. This decision would have been made by AchieveHigh2 and based on student output over the last three weeks.

"This isn't fair," complains Jessica, "this stuff is so boring."

"Shh!" cautions Kimberley, "Ms Taylor will hear us or the microphones will pick up your whining and you will get me into trouble - again!"

A learning agent pops up on Jessica's monitor and asks her if she needs assistance as her workstation has been inactive for a few minutes.

"God I hate that Merlin thingy" complains Jessica, "and if I see another piece of multimedia I'll puke!"

Suddenly all the monitors go black and pandemonium erupts. AchieveHigh2 has crashed - third time this week. For Jessica, Kimberley and the other Year 9 students it doesn't get much better than this, it will take about half an hour to reboot the system, time to chat - both girls reach for their mobile phones (Dede, 2002). 


\section{$2.2 \quad$ Scenario 2 - e-ngage, e-mpower, e-nable}

Jessica and Kimberley have arrived early. They know Ms Shaw will be in her room and will allow them to come in and do some work. They want to work on their project. Jess and Kim are in Year 9 at Sunshine High School and their home teacher is Ms Shaw. Ms Shaw is also their English and Studies of Society and Environment (SOSE) teacher. The girls love Ms Shaw and they love coming to school. At Sunshine High they have some cool technology - super-fast computers, with super-fast network and Internet connections in every room, and students have easy access to digital cameras, handheld computers, laptop machines, scanners and other peripherals. The girls are very adept at pushing data around the Internet and the network and they also have their personal digital communicators and assistants (PDCA). In the old days people carried a palm pilot, a mobile phone and a laptop computer- Jess and Kim giggle at the thought and think how clumsy all of that must have been. These days high speed wireless networks make the handling of data and communications through a PDCA so seamless that even Jess's little brother can do it and he's an idiot.

"You buy a PCDA like you used to buy a mobile phone," Jess tells Kim. "At least that's what my Dad says, but what would he know?"

But the cool technology is not why Jess and Kim love coming to school. School is a social event - chatting to Ms Shaw, the canteen, watching the Year 12 boys play football at lunch time, the debating club, the house athletics, swimming, netball, writing a story for the school magazine, deciding what to do on the weekend, art classes, learning to speak Chinese, school excursions, the school social, the deb ball in year 11, wood working, community service.

"You know what is the coolest thing about this school?" Jess says to Kim.

"The Year 12 boys?" ventures Kim. "The new sixty centimetre plasma screens?"

"No, it's the ......" replies Jess.

"Don't tell me I want to guess," interrupts Kim. "I know. It's being able to use your PCDA in class."

"No, although that is cool, the coolest thing is that we get to have a say about what it is we want to learn and how we learn. You know how Ms Shaw does all that brainstorming with us how what we do in Maths, Science and other subjects is all connected to the topic we are studying and how we get a chance to select the topic and the sort of activities we want to do and all that stuff - that's cool," says Jess.

"What? You're out of your tree. Those sixty centimetre plasma screens in the classroom - now that's cool. The stuff you're talking about, the schooly, 
teacher, learny thingy can never be cool - them's the rules - or have the rules changed?" enquires Kim.

"Yes they have," says Jessica.

As the girls approach the room their PCDAs vibrate and they read the message. Ms Shaw has gone to the staff room to get a cup of tea she will be back in five minutes. The message was not specifically sent to the girls by Ms Shaw, she did not know they were coming, but the smart technology incorporated into the building allows messages like this to be received as people approach the door. This sort of technology is now available in many buildings throughout the city, last week the girls went to the new museum, as they passed exhibits they could access, download, send and store information via their PCDAs, as well as interact with the many exhibits. The girls also use their PCDAs to pay for movie tickets, public transport; they can even use them to buy a can of coke from a vending machine.

Ms Shaw returns, she greets the girls and they all enter the classroom. A student from the 1990s would find difficulty in calling this a classroom, some things are familiar but others are straight out of Star Trek. There are pods of several small flat LCD screens as well as two large plasma screens, projectors, cameras, printers, and all sorts of other devices. There are some very comfortable looking sofas, office type chairs, an area for formal instruction, tables arranged for small group work, whiteboards, and displays of students' work. A closer examination of the whiteboards and the notice boards and it is easy to determine that the students are investigating the topic Australian Discovery and Exploration. There are lots of concept maps, questions and ideas displayed all over the place. On one noticeboard several sub topics and focus questions have been written, and projects assigned.

Some other students enter the room and pleasantries are exchanged. Without direction from Sue screens flicker and digital images illuminate the room. Matthew and Kate want to show the others what they have been working on. They are investigating the expeditions of Matthew Flinders and Nicholas Baudin. Through their PCDAs and the wireless network they have downloaded their latest work onto the school network and have it displayed on one of the large plasma screens. Using some very clever programming they have created a very interactive piece of multimedia that helps to answer several questions that the class has about the rivalry between Flinders and Baudin and the significance of their expeditions. It starts by tracing the voyages of the explorers on a map of the world and as the ships reach certain points on the map the user is invited to explore what happened at these locations. Kim, Jessica and Sue watch fascinated. The pair has used primary historical documents available online at French and British museums to build their project. The paintings done by artists and scientists on the Baudin exhibition are stunning and the sea charts of the Australian coast made by 
Baudin are exquisite. The love letters written by Flinders to the new bride he left behind for 10 years are interesting. Sue thinks about how she can use them to help the students understand the notions of duty, honour, and glory for queen and country and whether these things are still relevant today. It seems that Matthew has become very curious about the French and is talking about doing some research on some guy called Napoleon. Other teachers might reflect on the power of the technology and its impact on Matthew but Sue reflects on the power of curiosity. It drove Baudin, Flinders, generations of historians and scientists and academics and now it is driving Matthew. Curiosity may have killed the cat but the lust for wanting to know is probably one of the greatest gifts a teacher can nurture in her students. Sue thinks about how she can weave this thought into the students' learning.

Jessica and Kim have been investigating the First Fleet and are ready to show what they have done. Through the brainstorming done at the beginning of the topic they became very interested in what it was like to be a teenager on the First Fleet and a part of the First Settlement. They have decided to do this by presenting a series of two narratives - a female convict and a male convict. Their research has led then to primary documents available online, to several databases about the First Fleet, to an old Alan Ladd movie which they were able to download from the net and hundreds of web sites about the topic. They have decided that they will present the narratives to the class as a play. The play will be video taped for later reference. After the play the girls are going to get the class to pretend they have been transported and to write Postcards from Port Jackson back to their families in England. They have found some old quill pens for the activity. They love taking on the role of teacher when they present projects and have become very adept at choosing activities for the rest of the class that are challenging and engaging. Choosing not do a multimedia presentation has really put the pressure on Jessica and Kim. The writing of the narratives has to be spot on - crisp, accurate and entertaining. Sue is pleased with their choice as it gives her an opportunity to talk to the class about writing genres and writing for an audience. Kim and Jessica have the first narrative displayed on the screen. Kim gets a virtual agent to read the narrative and looks to the others for some feedback.

"That's horrible," states Matthew. "I would have just jumped overboard."

"Why don't you have some images on the plasma screens while you do the play?" suggests Kate.

Sue makes a few suggestions; the virtual agent makes some suggestions about spelling and grammar in the $18^{\text {th }}$ century. Jessica dictates the changes and the computer obliges. Jessica and Kim begin discussing the second narrative. 
As the rest of the class start to arrive Sue takes a couple of minutes to reflect on the impact technology has made to the teaching and learning environment. If she chooses she can access a range of virtual learning objects on every topic and concept under the sun. She sometimes uses them to fill gaps in her own knowledge and sometimes to help her explain specific concepts to groups of children. She rarely uses them to assemble a course because she wants the students to have some control and ownership of the curriculum. Other teachers tell Sue that all the brainstorming, integration of subjects and a multidisciplinary approach to the investigation of topics is messy. She looks across at Jess, Kim, Matthew, Kate, and the others entering the room and thinks about the commitment these kids make to their own learning - yes it is messy but it is worth it. With the technology Sue can bring the outside world to the classroom and take the classroom to the outside world. Recent breakthroughs in wireless networks, data compression and bandwidth make synchronous video communication cheap and real. Later today the class will link to the British Museum to look at Captain Cook's journal and when John comes in later for a Maths class they will link to the maritime museum at Plymouth in the United Kingdom to analyse the mathematics of ship building in the $18^{\text {th }}$ century.

For Sue and her students, the access to information, smart technology, bandwidth, PCDAs and other devices is stunning. When she first started teaching she never dreamed it would be like this and the breakthroughs they have made in the last 10 years have been astonishing. But the sobering thought is that students like Jess, Kim, Matthew and Kate are the privileged elite. For many in Australia the teaching and learning environment provided by this school is not accessible. For students in other parts of the world it is science fiction; the digital divide is wider than ever.

\section{CONCLUSION}

So what do the two scenarios tell about the trends, issues, and developments relating to the future of education and technology? I think the scenarios suggest that technology is changing the way we teach and the way we learn, but so is our increased understanding of how humans construct knowledge and achieve deep understanding. As the digital boundaries are pushed there is a temptation that the technology, and those developing the technology, will dictate how teaching and learning should happen in a digital world. There is danger in this hegemony for the likely outcome could well be scenario one, with the technology sector usurping a significant slice of the education budget and resulting in a whole lot of puking going on! However there is also danger in scenario two. The obvious danger is the widening of 
the digital divide but there is also danger in educators, through ignorance and arrogance, rejecting what the digital world has to offer.

The technology is important so is the recognition that teaching and learning is about curiosity, challenge, creativity, connectedness, excellence, engagement, and empowerment. Perhaps the most important thing of all to acknowledge is the desperate need for teachers like Sue Shaw with her ability to use the technology to help her establish powerful learning environments that are interesting, exciting, intellectually stimulating and underpinned by our understanding of the human condition. The technology matters, but good teachers matter more.

\section{REFERENCES}

Bajscy, R. (2002). Technologies and learning. Visions 2020. Washington, DC: U.S. Department of Commerce, Technology Administration Office.

Chen, M. \& Arnold, S. (2002). A day in the life of a young learner: A 2020 vision. Visions 2020. Washington, DC: U.S. Department of Commerce, Technology Administration Office of Public Affairs.

College of Marin (2002). Scenario Planning, College of Marin 835 College Ave Kentfield California. Retrieved October 17, 2002 from http://www.marin.cc.ca.us/scenario/ what_exactly_is.htm.

DE\&Ta (2002). Middle Years, State of Victoria (Department of Education \& Training). Retrieved October 17, 2002 from http://www.sofweb.vic.edu.au/mys/

DE\&Tb (2002). Early Years strategy, State of Victoria (Department of Education \& Training). Retrieved October 17, 2002 from http://www.sofweb.vic.edu.au/eys/index.htm.

Dede, C. (2002). Vignettes about the future of learning technologies. Visions 2020. Washington, DC: U.S. Department of Commerce, Technology Administration Office of Public Affairs.

Duffy, T. \& Cunningham, D. (1996). Constructivism: Implications for the design and delivery of instruction. In D. H. Jonassen (Ed.), Handbook of Research For Educational Communications and Technology. New York: Macmillan Library Reference USA.

Education Queensland (2002). The New Basics Project. The State of Queensland: Education Queensland.

Hannafin, M. \& Land, S. (1997). The foundations and assumptions of technology-enhanced student-centred learning environments. Instructional Science, 25, 167-202.

Hawkins, D. (1994). Constructivism: Some history. In P. Fensham, R. Gunstone \& R. White (Eds), The Content of Science: A Constructivist Approach to its Teaching and Learning. London: The Falmer Press.

Hinrichs, R. \& Gates, B. (2002). A vision for lifelong learning - Year 2020. Visions 2020. Washington, DC: U.S. Department of Commerce, Technology Administration Office of Public Affairs.

Mooneyham, J. R. (1993). The Rest of our Lives: What It'll Be Like. Retrieved October 17, 2002 from http://www.jrmooneyham.com/rest.html

NCREL (2002). Engauge, North Central Regional Educational Laboratory. Retrieved October 17, 2002 from http://www.ncrel.org/engauge/

Neumann, U. \& Kyriakakis, C. (2002). 2020 Classroom. Visions 2020. Washington, DC: U.S. Department of Commerce, Technology Administration Office of Public Affairs. 
Office of Technology \& Assessment (1994). Education and Technology: Future Visions. Washington DC, U.S. Congress. Retrieved October 17, 2002 from http://www.wws.princeton.edu/cgibin/byteserv.prl/ ota/disk1/1995/9522/9522.PDF

Pausch, R. (2002). A Curmudgeon's vision for technology in education. Visions 2020. Washington, DC: U.S. Department of Commerce, Technology Administration Office of Public Affairs.

Pearson, I. \& Cochrane, P. (1994). 200 Futures for 2020, BT Laboratories. 2002.

Ridgeway, J. \& Passey, D. (1991). A constructivist approach to educational computing. Australian Educational Computing 6(2), 4-9.

Romeo, G. I. (2000). Computers, constructivism and engaged learning: Sue Shaw's story. Australian Computers in Education Conference ACEC 2000. Melbourne: Computing in Education Group of Victoria \& Briter Solutions.

Schwartz, P. \& Australian Business Network. (1996). The Art of the Long View: Paths to Strategic Insight for Yourself and Your Company. St. Leonards, NSW: Australian Business Network.

Spender, D. \& Stewart, F. (2002). Embracing e-learning in Australian Schools. Melbourne, Commonwealth Bank. Retrieved October 17, 2002 from http:// about.commbank.com.au/GAC_File_Metafile/0,1687,2003\%255Fe\%252Dlearning\%255F report,00.pdf

U.S. Department of Commerce (2002). Visions 2020. Washington DC, U.S. Department of Commerce Technology Admnistration Office of Public Affairs. Retrieved October 17, 2002 from http://www.ta.doc.gov/reports/TechPolicy/2020Visions.pdf

VonGlaserfeld, E. (1991). Constructivism in education. In A. Lewy (Ed.), The International Encyclopedia of Curriculum. Oxford/New York: Pergamon Press. 